\title{
NOTES ON BEHAVIORS OF FREE-RANGING BLACK-FOOTED FERRETS: CONATA BASIN, SOUTH DAKOTA, 2007-2009
}

\author{
David A. Eads ${ }^{1}$
}

\begin{abstract}
During 2007-2009 in the Conata Basin, South Dakota, field studies provided opportunities to accumulate incidental observations of wild-born black-footed ferrets (Mustela nigripes) and their interactions with other species. Here, I describe maternal behaviors by female ferrets; interactions between a female ferret and a rattlesnake (Crotalus viridis viridis); and attacks by ferrets on a horned lark (Eremophila alpestris), a deer mouse (Peromyscus sp.), and a cottontail rabbit (Sylvilagus sp.). Additionally, I present hypotheses for future testing and discuss conservation implications.
\end{abstract}

Resumen._Durante 2007 a 2009 en la Cuenca Conata, Dakota del Sur, estudios de campo brindaron oportunidades para acumular observaciones incidentales del hurón de patas negras nacido en libertad (Mustela nigripes) y sus interacciones con otras especies. En el presente estudio, describo los comportamientos maternales de las hurones hembra, las interacciones entre estas hembras y una víbora de cascabel (Crotalus viridis viridis) y los ataques de hurones sobre una alondra cornuda (Eremophila alpestris), un ratón ciervo (Peromyscus sp.) y un conejo de cola de algodón (Sylvilagus sp.). Además, presento varias hipótesis para ser evaluadas en el futuro y discuto las implicaciones para la conservación.

During 2007-2009, I was part of 2 different teams of researchers studying black-footed ferrets (Mustela nigripes; hereafter "ferrets") in the Conata Basin, South Dakota. Researchers studied ferrets on 2 colonies of black-tailed prairie dogs (Cynomys ludovicianus): a 452-ha colony (colony SC07) and an adjacent 202-ha colony (colony SC24; Eads 2009, Eads et al. 201la, 2011b, D.E. Biggins unpublished data). The 2007-2009 research involved spotlight surveys (Biggins et al. 2006) during which observers collected behavioral observations of ferrets and other species (field protocols limited disturbance of wildlife while allowing collection of data that was later used to develop predictive models for ferrets). Herein, I describe observations of maternal behaviors by female ferrets; interactions between a female ferret and a rattlesnake (Crotalus viridis viridis); and attacks by ferrets on a Horned Lark (Eremophila alpestris), a deer mouse (Peromyscus sp.), and a cottontail rabbit (Sylvilagus sp.).

Maternal Behaviors of Female Ferrets

Ferrets often respond casually to humans (Miller 1988:72); however, when raising kits, adult female ferrets might regard humans as more threatening. In 2007-2008, two observations suggested female ferrets defend their kits from humans (at least in some cases). First, early in the 2007 season (14 Jun), I located a female at 01:41 as she carried her kits one by one by the nape, moving them between 2 burrow openings about $20 \mathrm{~m}$ apart. Eyeshine from spotlighted kits was not seen, suggesting their eyes had not yet opened. After transferring a second kit, the female returned to the first opening and descended. I approached with a flashlight to place an automated passive integrated transponder (PIT) tag reader at the opening to identify the adult female ferret (Biggins et al. 2006), and the female emerged carrying another kit (I was $>20 \mathrm{~m}$ away at that time). About midway between the 2 openings, she stopped, lowered her head to the ground, and then continued to the second opening (now containing at least 2 kits). After the female had descended below ground, I approached and placed the PIT-tag reader at the second opening. I heard barks (Miller 1988:44) from the location at which the female ferret had lowered her head to the ground. I cautiously approached to within approximately $10 \mathrm{~m}$ of the barks and used the flashlight to illuminate the area from which the barks emanated, but I stopped when the mother ferret emerged and jumped toward and away from me, hissing loudly (Miller 1988:44). The female ferret returned to the

${ }^{1}$ Graduate Degree Program in Ecology, Colorado State University, Fort Collins, CO 80523-1878. E-mail: david.eads@colostate.edu 
second burrow opening, but she did not fully descend into the burrow. I again illuminated the area from which the barks emanated, but I stopped when the adult female approached me ( $\sim 10 \mathrm{~m})$, curled her body sideways, and opened her mouth and hissed and "snarled" (see also Hillman 1968:13, Miller 1988:67-68). To limit further disturbance, I returned to the spotlight-vehicle (which was $\sim 50 \mathrm{~m}$ away) and then turned back with binoculars. About midway between the 2 burrow openings, the female grabbed a barking kit and transferred it to the second burrow opening. Perhaps the female behaved in ways to distract me from her kit. Indeed, various species use distraction displays in defense of offspring (Caro 2005).

At SC07 on 13 July 2008 (00:49), 2 observers (DAE and D. Marsh) placed a PIT-tag reader at a burrow opening containing female ferret 05-183 and her kits. As we retreated, female 05183 emerged, leading 7 kits in a single-file line to another burrow opening. One kit strayed about $10 \mathrm{~m}$ from the line and approached one of us (DM; see also Hillman 1968:13). As the remaining kits entered a burrow, their mother emitted a bark and sprinted toward the stray kit, ramming her head into the side of the kit (thereby pushing the kit to the ground; Hillman 1968, Clark et al. 1986, Miller 1988). Female $05-183$ then grabbed the kit by the nape and transferred it to the burrow containing the other kits. Perhaps the interaction served to reprimand the kit for dangerous behavior. Many animals, including Mustela (Poole 1972), can use contact and other interactions to help their young to identify dangerous situations (Caro and Hauser 1992, Hoppitt et al. 2008).

These 2 observations demonstrate that when moving kits among burrows, female ferrets might defend their kits when confronted by an extreme threat (e.g., a much larger potential predator), and they might reprimand their kits to teach them about dangerous behaviors. Ferrets have been characterized as having an accelerated life history, in which first-year fertility is high but first-year survival is low (Forrest et al. 1988, Marinari and Kreeger 2006, Grenier et al. 2007). Perhaps natural selection has favored female ferrets that vigorously protect their young when they perceive danger. Protection of offspring might increase kit survival and help a female ferret pass on her genes before she dies.

\section{Ferrets and Rattlesnakes}

Many predators that inhabit prairie dog colonies could kill ferrets, including rattlesnakes. At SC07 on 17 July 2008 (23:47), I located a female ferret (not identified) and a kit at a burrow opening. The female and her kit descended belowground and out of sight. I approached and knelt next to the occupied burrow opening to assemble an automated tag reader. While assembling the reader, I noticed a $0.6-\mathrm{m}$-long rattlesnake very close to the burrow opening. The rattlesnake undulated toward and into the burrow. After approximately $20 \mathrm{~s}$, I heard the snake's rattle and "hisses" from the snake and/or the ferret. I retreated, returning about 45 min later to find the rattlesnake at the burrow opening in a coiled position. Fearing for the female ferret's welfare, I intervened, using snake tongs to capture and release the rattlesnake $>200 \mathrm{~m}$ away in an area where I had not observed ferrets during previous surveys in that field season.

To date, it is not known if rattlesnakes kill ferrets. This seems plausible, however, given that ferrets and rattlesnakes can live in close proximity. Adult rattlesnakes could conceivably consume young ferrets, given that rattlesnakes prey on mammals of similar size (such as prairie dogs). If rattlesnakes kill and eat ferrets, it would be interesting to know if ferrets exhibit resistance to Crotalus venom, as exhibited in some mammals with an evolutionary association with rattlesnakes (e.g., some Otospermophilus ground squirrels-Poran et al. 1987). If ferrets did evolve some resistance to Crotalus venom, that resistance might no longer exist (or exist at a lower effectiveness), given the genetic bottleneck associated with early captive breeding efforts (10 ferrets started the breeding pool from which current ferrets are descended).

It is also possible that ferrets prey on rattlesnakes (Audubon and Bachman 1851). Some musteline carnivores attack and consume snakes. For instance, striped polecats (Ictonyx striatus) attack cobras (Shortridge 1934) and prey on colubrid snakes (RoweRowe 1978). Quick (1951) presented a water snake (Nerodia) to a caged long-tailed weasel (Mustela frenata), and the weasel attacked, killed, and partly consumed the snake. Perhaps on occasion, ferrets consume snakes, including rattlesnakes. 
Ferret Attacks on Species other than Prairie Dogs

Ferrets prey primarily on prairie dogs, but they occasionally eat other small mammals (Sheets et al. 1972, Campbell et al. 1987). During 2007-2009, ferrets were observed to pursue non-Cynomys on 3 occasions. The first instance involved a bird. On 3 August 2007 at SC07, I located female ferret 04-014 as she pounced between 2 burrow openings at 04:45. Nearby, a Horned Lark was crouched in a dirt road, using its bill to throw "dirt over its feathers" (dust-bathing; Beason 1995:9). The ferret noticed the lark and quickly approached. The lark fled vertically. Female 04-014 jumped, extending her forelegs toward the lark and missed contact with the bird. Henderson et al. (1969) describe observations of ferrets chasing (but not capturing) Horned Larks and Western Meadowlarks (Sturnella neglecta). Henderson et al. (1969) notes that Audubon and Bachman (1851), Roosevelt (1900), and Anthony (1937) include birds (and bird eggs) in a list of potential prey items for ferrets. In fact, in their description of $M$. nigripes, Audubon and Bachman (1851) included Audubon's drawing of a ferret inspecting a bird's nest. In the future, investigators could locate areas occupied by ferrets and, in those areas, assemble cameras at nests of ground-nesting birds (e.g., Mountain Plovers, Charadrius montanus) in an attempt to document depredation of bird eggs by ferrets. This approach to observation has proven useful. For instance, P. Skrade and S. Dinsmore (Iowa State University, personal communication) used cameras to document depredation of C. montanus nests by a coyote (Canis latrans) and, on a separate occasion, a Black-billed Magpie (Pica hudsonia). Ferrets might also kill and consume Burrowing Owls (Athene cunicularia) that live in prairie dog burrows (Henderson et al. 1969), but such predation has not been documented.

The remaining attacks on non-Cynomys species involved small mammals. At SC07 on 23 June 2008, I located a ferret (not identified) that was chasing a cottontail rabbit between 2 burrow openings at 00:32. The ferret chased the rabbit for about $15 \mathrm{~m}$ and then sought refuge at a burrow opening. During 2 subsequent chases, the rabbit jumped erratically, hopping into the air and quickly extending and retracting its hind legs before landing and hopping again. During a final chase, the rabbit ran >50 $\mathrm{m}$ away; the ferret stopped in a burrow opening and peered at me. Perhaps the jumps by the rabbit advertised strength and speed to deter pursuit by a predator-like stotting in Thomson's gazelles (Eudorcas thomsonii) pursued by African wild dogs (Lycaon pictus) (Fitzgibbon and Fanshawe 1988). In flight, the rabbit appeared to avoid burrow openings. Being faster than ferrets $\left(10.46 \mathrm{~m} \cdot \mathrm{s}^{-1}\right.$ for a Sylvilagus - Biggins and Biggins 2006), rabbits might have an advantage in the open (compared to near or in burrows). In contrast to the rabbit, the ferret (when not in active pursuit of the rabbit) remained near a burrow opening, perhaps to avoid attacks from other predators (e.g., coyotes often hunt rabbits). Audubon and Bachman (1851) and Roosevelt (1900) include rabbits in their lists of prey items for ferrets. Henderson et al. (1969) report an observation by R. Gerhardt (in 1963) in which a ferret chased a cottontail rabbit down a trail in Wyoming. Henderson et al. (1969) also describe an experiment in Mellette County, South Dakota, in which a cottontail rabbit was tethered and placed in burrow openings at which a ferret was observed. The ferret killed and apparently consumed the rabbit. Hillman (1968) also notes that Mellette County ferrets killed tethered rabbits. In Meeteetse, Wyoming, snow tracking indicated that ferrets attack and kill rabbits (Clark et al. 1986). Rabbits were rarely found in ferret scat in Meeteetse (Campbell et al. 1987), but scat does not elucidate the frequency of ferret attacks on rabbits (given that a ferret will not always capture a rabbit).

The last observed attack on non-Cynomys species involved a deer mouse. On 23 June 2009 at SC24, 2 observers (DAE and S. Ramakrishnan) located female ferret 07-170 at 22:43. The ferret, in pursuit of a deer mouse scurrying near a burrow opening, shifted side to side in quick motions as her head and forelegs moved back and forth. The mouse fled aboveground, and the ferret remained at the burrow opening, peering at the observers. In Montana, S. Hargreaves (Wild Guardian Media, personal communication), then with the U.S. Fish and Wildlife Service, observed and videorecorded similar interactions between a ferret and a vole (Microtus sp.); in that event, the ferret captured the vole.

On the basis of fecal analyses, small rodents, including Peromyscus and Microtus species, seemingly comprise a small portion of a 
ferret's diet (Sheets et al. 1972, Campbell et al. 1987). Nonetheless, Peromyscus, Microtus, and other small rodents could be important food when prairie dogs are scarce or temporarily unavailable, but the small rodents can be infected by and carry Yersinia pestis, the plaguecausing bacterium (Stapp et al. 2008). In consuming small rodents (including carcasses), ferrets can consume $Y$. pestis and die (given ferrets are highly susceptible to plague). Indeed, captive ferrets have died of plague after eating infectious prairie dog meat (Godbey et al. 2006), and closely related Siberian polecats (Mustela eversmanni) died of plague after eating a single plague-killed lab mouse (10 of 12 polecats died; Castle et al. 2001). This consumptive route of $Y$. pestis transmission (Rust et al. 1972) could have important implications for ferrets. Namely, if insecticides are used to protect ferrets and prairie dogs from infectious fleas (vectors of $Y$. pestis), ferrets might still eat infectious Peromyscus or Microtus and die (e.g., infectious mice that moved into a prairie dog colony from an area without insecticide treatment) (see Godbey et al. 2006 for further discussion). It would be interesting to collect scat from ferrets at reintroduction sites to investigate how often ferrets consume nonCynomys rodents, and if these rodents comprise a greater proportion of the ferret diet at certain sites. Perhaps the consumptive route of plague transmission (from non-Cynomys to ferrets) is relatively common at some sites (suggesting an increased need to immunize ferrets against plague at those sites).

\section{ACKNOWLEDGMENTS}

The 2007-2008 research was conducted with J. Millspaugh, D. Biggins, D. Jachowski, T. Livieri, and D. Marsh and was funded by State Wildlife Grant T35, study number 2435, provided by the South Dakota Department of Game, Fish and Parks; the National Fish and Wildlife Foundation (grant number 2006-00580000); the United States Fish and Wildlife Service; the United States Forest Service; the United States Geological Survey; the Denver Zoological Foundation (DZF); Prairie Wildlife Research; and the University of Missouri. The 2009 research was conducted by the U.S. Geological Survey (USGS-D. Biggins) and was funded by the USGS and the DZF. Discussions with D. Biggins, J. Millspaugh, and T. Livieri, and a review of these notes by D. Biggins and an anonymous reviewer, were greatly appreciated.

\section{Literature Cited}

Anthony, H.E. 1937. Mammals of America. Garden City Publishing Co., New York, NY.

Audubon, J.J., And J. Bachman. 1851. The viviparous quadrupeds of North America. Volume II. V.G. Audubon, New York, NY.

Beason, R.C. 1995. Horned Lark. No. 195 in A. Poole and F. Gill, editors, The birds of North America. American Ornithologists' Union, Academy of Natural Sciences of Philadelphia, Philadelphia, PA.

BigGins, D.E., AND D.M. BigGINS. 2006. Bobcat attack on a cottontail rabbit. Southwestern Naturalist 51:119-122.

Biggins, D.E., J.L. Godbey, M.R. Matchett, L.R. Hanebury, T.M. Livieri, And P.E. Marinari. 2006. Monitoring black-footed ferrets during reestablishment of free-ranging populations: discussion of alternative methods and recommended minimum standards. Pages 155-174 in J.E. Roelle, B.J. Miller, J.L. Godbey, and D.E. Biggins, editors, Recovery of the black-footed ferret: progress and continuing challenges. U.S. Geological Survey Scientific Investigations Report 2005-5293.

Campbell, T.M., III, T.W. Clark, L. Richardson, S.C. ForRest, AND B.R. Houston. 1987. Food habits of Wyoming black-footed ferrets. American Midland Naturalist 117:208-210.

CARo, T. 2005. Antipredator defenses in birds and mammals. University of Chicago Press, Chicago, IL.

Caro, T.M., and M.D. Hauser. 1992. Is there teaching in nonhuman animals. Quarterly Review of Biology 67:151-174.

Castle, K.T., D. Biggins, L.G. Carter, M. Chu, K. InNES, AND J. WIMSATT. 2001. Susceptibility of the Siberian polecat to subcutaneous and oral Yersinia pestis exposure. Journal of Wildlife Diseases 37: $746-754$.

Clark, T.W., L. Richardson, S.C. Forrest, D.E. Casey, and T.M. CAMPBELL. 1986. Descriptive ethology and activity patterns of black-footed ferrets. Great Basin Naturalist Memoirs 8:115-134.

EADS, D.A. 2009. Evaluation and development of blackfooted ferret resource selection function models. Master's thesis, University of Missouri, Columbia, MO.

Eads, D.A., J.J. Millspaugh, D.E. Biggins, D.S. JaChOWski, AND T.M. LIVIERI. 2011a. Evaluation of a black-footed ferret resource utilization function model. Journal of Wildlife Management 75:1155-1163.

Eads, D.A., J.J. Millspaugh, D.E. Biggins, T.M. Livieri, AND D.S. JaCHOWsKI. 2011b. Post-breeding resource selection by adult black-footed ferrets in the Conata Basin, South Dakota. Journal of Mammalogy 92: 760-770.

Fitzgibbon, C., and J. Fanshawe. 1988. Stotting in Thomson gazelles-an honest signal of condition. Behavioral Ecology and Sociobiology 23:69-74.

Forrest, S.C., D.E. Biggins, L. Richardson, T.W. Clark, T.M. Campbell III, K.A. Fagerstone, and E.T. Thorne. 1988. Population attributes of the blackfooted ferret (Mustela nigripes) at Meeteetse, Wyoming, 1981-1985. Journal of Mammalogy 69:261-273.

Godbey, J.L., D.E. Biggins, and D. Garelle. 2006. Exposure of captive black-footed ferrets (Mustela 
nigripes) to plague (Yersinia pestis) and implications for species recovery. Pages 233-237 in J.E. Roelle, B.J. Miller, J.L. Godbey, and D.E. Biggins, editors, Recovery of the black-footed ferret: progress and continuing challenges. U.S. Geological Survey Scientific Investigations Report 2005-5293.

Grenier, M.B., D.B. McDonald, and S.W. Buskirk. 2007. Rapid population growth of a critically endangered carnivore. Science 317:779.

Henderson, F.R., P.F. Springer, and R. Adrian. 1969. The black-footed ferret in South Dakota. South Dakota Department of Game, Fish \& Parks Technical Bulletin No. 4.

Hillman, C.N. 1968. Life history and ecology of the black-footed ferret in the wild. Master's thesis, South Dakota State University, Brookings, SD.

Hoppitt, W.J.E., G.R. Brown, R. Kendal, L. Rendell, A. Thornton, M.M. Webster, and K.N. Laland. 2008. Lessons from animal teaching. Trends in Ecology and Evolution 23:486-493.

Marinari, P.E., and J.S. Kreeger. 2006. An adaptive management approach for black-footed ferrets in captivity. Pages 23-36 in J.E. Roelle, B.J. Miller, J.L. Godbey, and D.E. Biggins, editors, Recovery of the black-footed ferret: progress and continuing challenges. U.S. Geological Survey Scientific Investigations Report 2005-5293.

MilleR, B.J. 1988. Conservation and behavior of the endangered black-footed ferret (Mustela nigripes) with a comparative analysis of reproductive behavior between the black-footed ferret and the congeneric domestic ferret (Mustela putorius furo). Doctoral dissertation, University of Wyoming, Laramie, WY.

PooLE, T.B. 1972. Some behavioral differences between the European polecat, M. putorius, the ferret, M. furo, and their hybrids. Journal of Zoology 166:25-35.
Poran, N.S., R.G. Coss, and E. Benjamini. 1987. Resistance of California ground squirrels (Spermophilus beecheyi) to the venom of the northern Pacific rattlesnake (Crotalus viridis oreganus): a study of adaptive variation. Toxicon 25:767-777.

Quick, H.F. 1951. Notes on the ecology of weasels in Gunnison County, Colorado. Journal of Mammalogy 32:281-290.

Roosevelt, T. 1900. The wilderness hunter. G.P. Putnam's Sons, New York, NY.

Rowe-Rowe, D.T. 1978. Comparative prey capture and food studies of South African mustelines. Mammalia 42:175-196.

Rust, J.H., D.N. Harrison, J.D. Marshall, and D.C. Cavanaugh. 1972. Susceptibility of rodents to oral plague infection: a mechanism for the persistence of plague in inter-epidemic periods. Journal of Wildlife Diseases 8:127-133.

SheEts, R.G., R.L. Linder, and R.B. Dalhgren. 1972. Food habits of two litters of black-footed ferrets in South Dakota. American Midland Naturalist 87: 249-251.

SHortridge, G.C. 1934. The mammals of south west Africa. Volume 1. William Heinemann Limited, London, United Kingdom. 437 pp.

Stapp, P., D.J. Salkeld, R.J. Eisen, R. Pappert, J. Young, L.G. Carter, K.L. Gage, D.W. Tripp, and M.F. ANTOLIN. 2008. Exposure of small rodents to plague during epizootics in black-tailed prairie dogs. Journal of Wildlife Diseases 44:724-730.

Received 30 June 2011 Accepted 13 February 2012 